\title{
Spatial and temporal dynamics of phytoplankton communities in a Great Lakes drowned river-mouth lake (Mona Lake, USA)
}

\author{
Nadezhda D. GILLETT, ${ }^{* *}$ Mark R. LUTTENTON, Alan D. STEINMAN \\ Annis Water Resources Institute, Grand Valley State University, 740 West Shoreline Drive, Muskegon, MI 49441, USA \\ *Corresponding author: nadezhds@pdx.edu \\ \#Current address: Environmental Science and Management, Portland State University, PO Box 751, Portland, OR 97207, USA
}

\begin{abstract}
Drowned-river mouth lakes, transitional zones between a lake and an inflowing river, have unique physical and hydrological dynamics. However, our knowledge about these ecosystems and their phytoplankton communities is limited by data availability, especially how well they conform to conventional phytoplankton models, such as the Plankton Ecology Group (PEG). We sampled Mona Lake, MI, on a monthly basis between May 2002 and August 2003 to: i) describe phytoplankton community structure (species composition and functional groups) in three hydrologic zones (Great Lake-influenced, transitional, and lotic-influenced) and at four temporal scales (spring, summer, fall, and winter); and ii) assess whether the phytoplankton dynamics in Mona Lake can be explained by PEG. Distinct patterns in Mona Lake phytoplankton communities and functional groups were not evident among the three hydrologic zones, which can be explained, at least in part, by the horizontally well-mixed waters in this system. However, there was a strong seasonal change in phytoplankton composition and functional groups, with summer dominance by large filamentous cyanobacteria with aerotopes, nitrogen-fixing Nostocaleans, and diatoms. In general, seasonal changes were related to increasing levels of dissolved oxygen and $\mathrm{pH}$ in spring, total phosphorus and temperature in summer, and ammonia in fall. Phytoplankton dynamics in Mona Lake were partially explained by the PEG model; our observations revealed different fall (cyanobacteria and chlorophytes) and winter (chlorophytes and dinoflagellates) communities than predicted. Temporal influence resulted in distinct changes in phytoplankton dynamics, whereas the hydrologic influence tended to homogenize phytoplankton community structure in this drowned river-mouth lake. This seasonal change conformed relatively well to the PEG model, which might have predictive applications in the management (e.g., control of algal blooms) of the lake.
\end{abstract}

Key words: Phytoplankton, functional groups, Lake Michigan, drowned river-mouth lake, Plankton Ecology Group (PEG) model.

Received: July 2014. Accepted: January 2015.

\section{INTRODUCTION}

Drowned river-mouth lakes form dynamic transition zones between lotic and lentic systems, and often are characterized by high rates of biological productivity (Larson et al., 2013). These lakes are common along Lake Michigan's eastern shoreline where they can be influenced by both a Great Lake and inflowing river water (Albert et al., 2005). Similar to estuarine systems, these lakes serve as hydrologic mixing zones, processing material moving both from the watershed to Lake Michigan and from Lake Michigan back up to the watershed (Larson et al., 2013). The geological history of drowned river-mouth lakes dates back $\sim 10,000$ years when the last glaciers retreated to the north and the rising Great Lakes water levels flooded the eroded river mouths. Their complex hydrodynamics can influence material transport and processing, with associated implications for biological structure and function (Trebitz et al., 2009; Larson et al., 2013). For example, fish composition within coastal wetlands differs depending on their Great Lake connectivity (i.e., lacustrine-protected $v s$ barrier-beach lagoons, Trebitz et al., 2009). Due to their locations near areas of development and human population centers, many of these drowned river-mouth lakes are heavily utilized by humans, which can result in ecological impairment and loss of ecosystem services (cf. Riseng et al., 2010). However, our understanding of drowned river mouth hydrodynamics is limited by data availability.

The unique hydrologic nature of drowned river-mouth lakes also may influence phytoplankton dynamics; it is unclear how well the phytoplankton follows the expected pattern of change common to north temperate lakes. The seasonal succession of freshwater plankton in a standard lake is described in the Plankton Ecology Group (PEG) model (Sommer et al., 1986). According to this model, phytoplankton development starts with small cryptophytes and small centric diatoms in spring under an abundance of nutrients and light. In early summer, when nutrients are still available, cryptophytes and chlorophytes develop. They are followed by large diatoms when nutrients such as phosphorus are still available. In summer, when silica becomes the limiting nutrient and temperature is high, diatom growth is constrained and dinoflagellates or cyanobacteria dominate. Finally, in autumn there is a 
shift back to diatoms as the mixing depth increases, light conditions deteriorate, and nutrients become available again. More recently, seasonal changes in species composition may include toxin-producing species (harmful algal blooms, HABs) that may pose ecological and human health risks (Ibelings and Chorus, 2007).

Phytoplankton composition can be very diverse as it encompasses organisms with different morphologies (e.g., unicellular prokaryotic and colonial eukaryotic organisms with various shapes and sizes) and phylogenetic histories. As a result, multiple species inhabit the same environment and share the same resources (paradox of the plankton, Hutchinson, 1961). These species associations constitute functional groupings with similar morphological, ecological, and physiological traits (Reynolds et al., 2002; Kruk et al., 2010; but see Narwani et al., 2013), whose trade-offs allow for the coexistence of multiple species (Litchman and Klausmeier, 2008). For example, many HAB producing algae have differing eco-physiological traits, which may enable them to co-exist or dominate depending on local environmental conditions (Litchman et al., 2010; Carey et al., 2012). Two widely used functional classifications are based on species ecological preferences (Reynolds et al., 2002; Borics et al., 2007; Padisak et al., 2009) or their morphology (Kruk et al., 2010). Therefore, we chose to use functional groups as an additional way to understand phytoplankton dynamics in understudied drowned rivermouth lakes, many of which are experiencing a decline in water quality due to eutrophication and HABs.

The harmful algal blooms are one of the major impairments affecting Mona Lake, a drowned river-mouth lake with water quality degradation and a history of impairment (Evans, 1992; Steinman et al., 2006). Mona Lake's two main tributaries experienced pollution from various industries (e.g., petroleum refinery, metal finishing plant, superfund site) and are placed on the state of Michigan's 303(d) list for impaired fish and macroinvertebrate communities. The lake itself is surrounded by residential development and is subjected to urban runoff and associated nonpoint source pollution. High nutrient concentrations (excessive phosphorus loading) from external (Steinman et al., 2006) and internal (Steinman et al., 2009) sources have resulted in summer phytoplankton blooms, anoxic conditions, and fish kills in Mona Lake from the 1950's through the 1980's (Evans, 1992). Collectively, these activities have led to degradation of water quality, occurrence of HABs, and disrupted food webs (Steinman et al., 2006). In the summer of 2007 , microcystin concentrations (the most common toxin produced by HABs) reached 317 $\mu \mathrm{g} / \mathrm{L}$ (Rick Rediske, personal communication), which is $\sim 16$ times greater than the $20 \mu \mathrm{g} / \mathrm{L}$ standard for recreational water usage (WHO, 1999). Several potentially toxic cyanobacteria genera, including Microcystis and Cylindrospermopsis, have been observed in Mona Lake
(Hong et al., 2006). Given the extant information on this river-mouth system, it represented a good candidate for examining phytoplankton dynamics across spatial and temporal scales.

Our objectives were to describe phytoplankton species composition and functional groups (Reynolds et al., 2002; Kruk et al., 2010) in three hydrologic zones (Great Lakeinfluenced, lotic-influenced, and transitional) and at four temporal scales (spring, summer, fall, and winter); and assess whether the phytoplankton dynamics in Mona Lake can be explained with conventional phytoplankton models, such as PEG.

\section{METHODS}

\section{Study site}

Mona Lake is a small $\left(2.65 \mathrm{~km}^{2}\right)$, shallow (mean depth $\sim 5 \mathrm{~m}$ ), drowned river-mouth lake located in Western Michigan (Fig. 1). The lake discharges to the west into Lake Michigan through a dredged navigational channel, which also can provide bidirectional flow to and from Lake Michigan (Steinman et al., 2006). Mona Lake is dimictic, stratifying in the summer and freezing in most winters. The Mona Lake watershed $\left(\sim 200 \mathrm{~km}^{2}\right)$ includes two main tributaries and a number of small inflows to Mona Lake. The major land uses include forest (35\%), urban/developed (32\%), and agriculture (17\%). Most of the population in the watershed is in the immediate surroundings of the lake (Evans, 1992) where the impervious area is $>22 \%$ (Steinman et al., 2006). Hydraulic residence times (HRT) vary from $\sim 1$ month in wet conditions to $\sim 4$ months under dry conditions (Evans, 1992); this relatively short HRT reflects the lake's almost reservoir-like nature, serving as a short-term detention zone before discharging to Lake Michigan.

\section{Field sampling and lab analysis}

Monthly sampling was conducted at four sites (Fig. 1), covering the hydrological gradient of the lake. Study sites were selected to capture three zones of differing hydrological influences: Great Lake-influenced (Site 1, closest to Lake Michigan), transitional (Sites 2 and 3), and lotic-influenced (Site 4). Site 4 is most strongly influenced by tributary inflow, due to its proximity to Black Creek and Cress Creek, which contribute a combined $82.5 \%$ of the annual inflow to Mona Lake (Steinman et al., 2006). Sampling was conducted between May and October 2002, and again between February and August 2003 (excluding March), resulting in 48 phytoplankton samples. At each site, field measurements and water quality samples were taken at 1 $\mathrm{m}$ below the lake surface and at $1 \mathrm{~m}$ above the lake bottom (96 samples total). Field measurements including water temperature, dissolved oxygen, conductivity, total dissolved solids, turbidity, $\mathrm{pH}$, oxidation-reduction potential were ob- 
tained with a Hydrolab DataSonde 4a. Water quality samples were collected with Van Dorn bottles, transferred to acid-washed bottles, and stored on ice until returned to the laboratory. Water quality variables included chloride, sulfate, nitrate (analyzed by ion chromatography on a Dionex DX500; APHA 1999), ammonium, total Kjeldahl nitrogen, soluble reactive phosphorus, total phosphorus (analyzed on BRAN-LUEBBE Autoanalyzer; US EPA, 1983), alkalinity, and chlorophyll $a$. Water clarity was measured with a Secchi disk and irradiance with a Li-Cor quantum sensor. Samples for chlorophyll $a$ were analyzed in the laboratory using standard methods (APHA, 1999). Two unexpected events happened in the summer of each sampling year. The first event was a lift station failure in Little Black Creek (Fig. 1) on July 28, 2002 when approximately $750 \mathrm{~m}^{3}$ of raw sewage flowed into Mona Lake near site 3 . The second event was an algaecide treatment with copper sulfate $\left(\mathrm{CuSO}_{4}\right)$ on July 10, 2003.

Phytoplankton samples, collected with Van Dorn bottles at $1 \mathrm{~m}$ below the water surface and $1 \mathrm{~m}$ above the lake bottom, were integrated over depth for each site. Each sample was fixed with Lugol's solution (1\% final concentration). Identification and enumeration of phytoplankton cells were done at $450 \mathrm{x}$ or $1000 \mathrm{x}$ on a Nikon Eclipse TE200 inverted microscope under phase contrast illumination using the settling technique of Utermöhl (1958). Between 200-300 algal units (cells or filaments) were counted from each sample. Algal taxon biovolume was estimated with mathematical formulae for their appropriate geometric shapes (Hillebrand et al., 1999). Individual taxa biovolumes were multiplied by their corresponding units to obtain total taxa biovolume per sample. Relative biovolume was used in all subsequent analyses in order to make species abundance more comparable among samples. Each taxon was assigned to an ecologically-based functional group (FG; Reynolds et al., 2002; Borics et al., 2007; Padisak et al., 2009) and a morphologically-based functional group (MBFG; Kruk et al., 2010). Since phytoplankton samples at each site were integrated over different depths, whereas the environmental data were

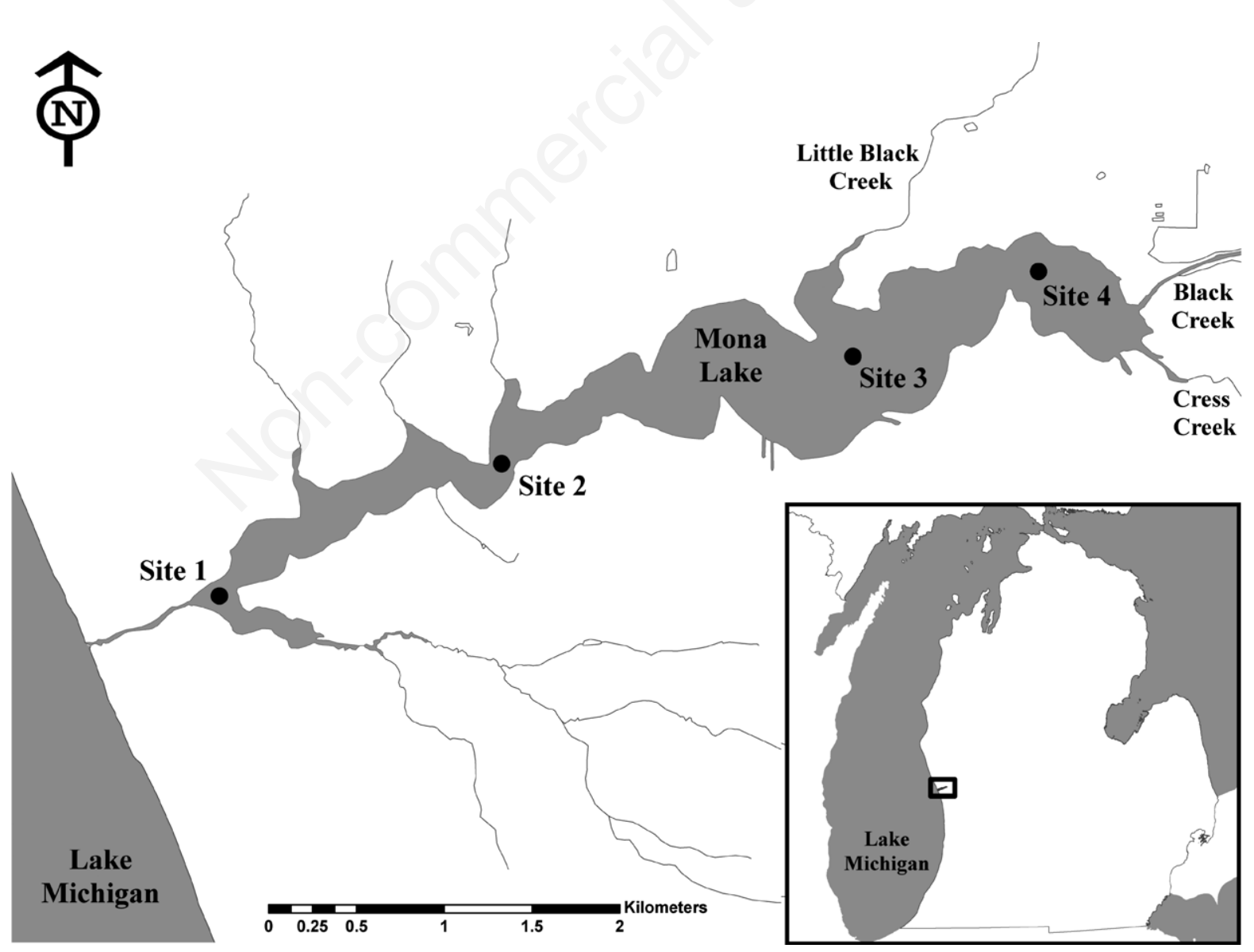

Fig. 1. Map of Mona Lake with locations of sampling sites. Site 1 (Great Lake-influenced is closest to Lake Michigan), sites 2 and 3 are transitional, site 4 is lotic-influenced (close proximity to the lake's main tributary). Inset: location of Mona Lake watershed within Michigan's lower peninsula. 
collected from two discrete depths (surface and bottom), we averaged the environmental data from each site for all analyses that involved a relation between phytoplankton and their environment.

\section{Data analysis}

To examine whether environmental conditions between surface and bottom samples were significantly different $(\alpha=0.05)$, we used $t$-tests or Wilcoxon rank-sum tests (when assumptions were not met). To assess the presence of spatial (four sites) and temporal (monthly) patterns in phytoplankton biovolume and chlorophyll $a$, a one-way analysis of variance (ANOVA) was used. Monthly samples were treated as independent events because phytoplankton communities change rapidly due to the short life cycles of their species and the relatively short HRT in Mona Lake. Values that did not approximate normal distributions were $\log _{10}$ or square root-transformed. If transformations did not result in normalized distribution, the non-parametric Kruskal-Wallis test was used. Statistically significant $(\alpha=0.05)$ differences were further analysed with pairwise t-tests with Bonferroni correction for multiple comparisons.

To describe phytoplankton communities in the three hydrologic zones (Great Lake-influenced, lotic-influenced, and transitional) and at the two temporal scales (fast and slow HRT), we used non-metric multidimensional scaling (NMDS) ordination. NMDS used the BrayCurtis similarity coefficient as a distance measure (Bray and Curtis, 1957), after exclusion of rare taxa $(<1 \%$ of sample's relative biovolume). Solutions with stress values $<20$ were considered good ordinations (Clarke, 1993). To identify environmental variables (fitted as linear vectors) related to the phytoplankton communities, the function envfit was used (Oksanen et al., 2009). The significance $(\alpha=0.05)$ of each vector was assessed with a goodness-offit statistic $\left(\mathrm{r}^{2}\right)$ using 1000 permutations. Ordinations were based on species data, phylogenetic, and functional groups. Temporal scale was defined by four seasons: spring (March-May), summer (June-August), fall (September-November), and winter (December-February). To assess whether the phytoplankton dynamics in Mona Lake can be explained with conventional phytoplankton models, such as PEG, the NMDS ordination representing major algal divisions was used. All data analyses were completed in $\mathrm{R}$ language and environment for statistical computing (R Development Core Team, 2012).

\section{RESULTS}

\section{Environmental conditions}

Most environmental conditions in Mona Lake varied over space and time. Spatially, there were gradual changes from site 1 (Great Lake-influenced, closest to Lake Michi- gan) to site 4 (lotic-influenced), including depth and Secchi disc transparency (site $1,7.98 \mathrm{~m}$ and $0.78 \mathrm{~m}$, respectively; site 4, $4.12 \mathrm{~m}$ and $0.60 \mathrm{~m}$, respectively) (Fig. $2 \mathrm{G}-\mathrm{H}$ ). In contrast, variables such as DO (6.39 to $\left.8.11 \mathrm{mg} \mathrm{L}^{-1}\right), \mathrm{pH}$ ( 8.25 to 8.52 ), turbidity ( 13.07 to 21.48 NTUs), chlorophyll $a$ (12.66 to $22.79 \mu \mathrm{g} \mathrm{L}^{-1}$ ), and light extinction coefficient (1.72 to 2.53) exhibited the opposite pattern (Fig. 2).

Spatial differences throughout the lake may be masked by site-level differences between surface and bottom samples. Except for chlorophyll $a$ (Fig. 2A), the variables that had somewhat higher concentrations on the bottom were ammonia, conductivity (Fig. 2B), SRP, total alkalinity, TKN (Fig. 2D), and TP (Fig. 2E). In contrast, DO (Fig. 2C) and temperature (Fig. 2F) were lower at the lake bottom compared to the surface. Bottom DO concentrations increased from site 1 (Great Lake-influenced) to site 4 (loticinfluenced), while TKN and TP declined in the same direction. Overall, some environmental variables (e.g., chlorophyll $a$, chloride, nitrate, sulphate, and turbidity) were the same $(\mathrm{P}>0.05)$ at the surface and the bottom of the lake (Tab. 1).

Temporally, mean DO was highest $\left(13.35 \mathrm{mg} \mathrm{L}^{-1}\right)$ in April 2003 and lowest (3.69 mg L $\mathrm{m}^{-1}$ ) in August 2002 (data not shown). The highest chloride concentration $(94.5 \mathrm{mg}$ $\left.\mathrm{L}^{-1}\right)$ and conductivity $\left(516.00 \mu \mathrm{S} \mathrm{cm}^{-1}\right)$ were observed in February 2003 potentially due to road salt runoff. The highest transmissivity was observed in April 2003 when Secchi disk depth was $0.91 \mathrm{~m}$ and the light extinction coefficient was 1.40 .

Mean chlorophyll $a$ concentration was $18.22 \mu \mathrm{g} \mathrm{L}^{-1}$ (Tab. 1), with the highest value ( $\left.46.38 \mu \mathrm{g} \mathrm{L}^{-1}\right)$ occurring in May 2003. Mean chlorophyll concentrations in the summers (July and August) of 2002 and 2003 were $<10$ $\mu \mathrm{g} \mathrm{L}^{-1}$. The largest among-sites variation (12.25-52.00 $\mu \mathrm{g}$ $\mathrm{L}^{-1}$ ) in chlorophyll concentration was measured in May 2002. The mean phytoplankton biovolume was $23.0 \times 10^{6}$ $\mu \mathrm{m}^{3} \mathrm{~mL}^{-1}$ (range $0.4-115.4 \times 10^{6} \mu \mathrm{m}^{3} \mathrm{~mL}^{-1}$ ). The highest mean biovolume $\left(95.3 \times 10^{6} \mu \mathrm{m}^{3} \mathrm{~mL}^{-1}\right)$ was recorded in July 2003 , while the lowest concentration $\left(1.7 \times 10^{6} \mu \mathrm{m}^{3}\right.$ $\mathrm{ml}^{-1}$ ) was measured in February 2003. There were no significant $(\mathrm{P}>0.05)$ differences in biovolume and chlorophyll $a$ concentrations among sites, but there were significant differences $(\mathrm{P} \leq 0.05)$ among sampling dates. Mean monthly phytoplankton biovolumes in May, July, and August of 2003 were significantly higher than the rest of the samples.

\section{Phytoplankton community structure}

A total of 94 taxa were observed during the course of this study. The most diverse group of algae was the chlorophytes (35 taxa) followed by cyanobacteria (29) and diatoms (17). The remaining algal divisions included dinoflagellates (5 taxa), euglenoids (4), cryptophytes and chrysophytes ( 2 taxa each). The average taxa richness in 
a sample was 17 (range of 5-31). The lowest average taxa number (8) per month was observed in August 2002 (one month after the sewage spill), while the highest (29) was observed in October 2002. Species with the highest mean relative biovolumes in the study included Planktothrix agardhii (Gomont) Anagnostidis \& Komárek (mean $15.2 \%$, range $0-78.5 \%, 31$ samples), Scenedesmus quadricauda (Turpin) Brébisson (mean 9.9\%, range 0-67.6\%, a)

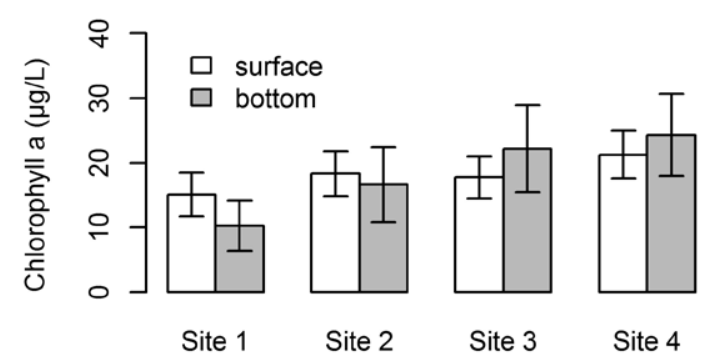

c)

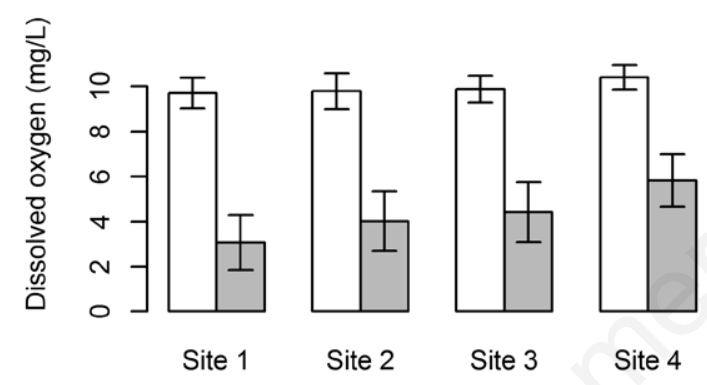

e)

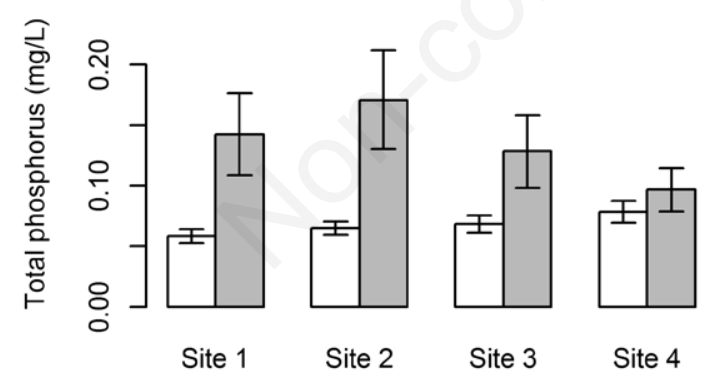

g)



b)
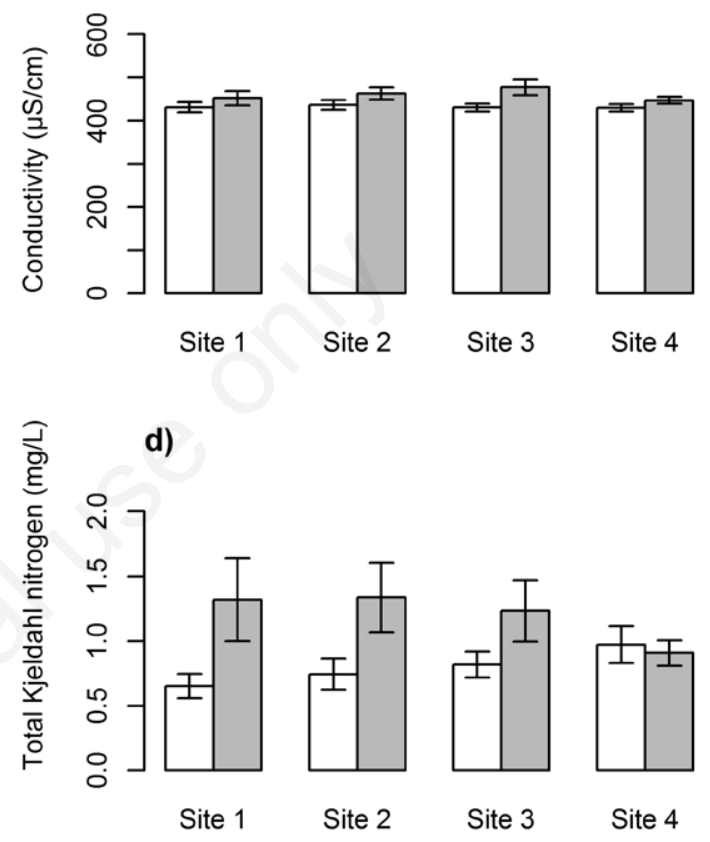

f)

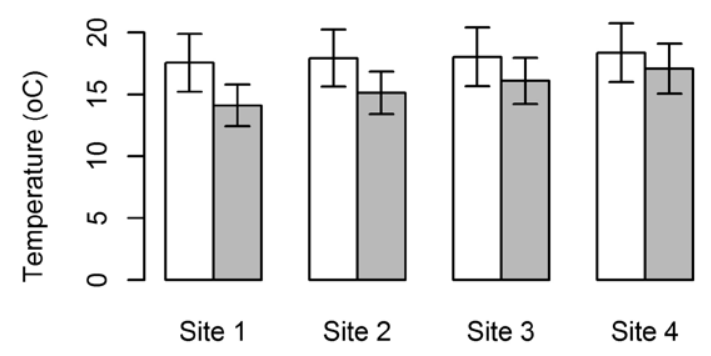

h)



Fig. 2. Barplots (mean \pm SE) for selected environmental variables summarized for surface and bottom samples for each sampling site (site 1 is Great Lake-influenced, site 4 is lotic-influenced). See Fig. 1 for site locations. 
37 samples), Aphanizomenon gracile (Lemmermann) Lemmermann (mean $8.4 \%$, range $0-64.0 \%, 18$ samples), and Pseudanabaena sp. Lauterborn (mean $8.0 \%$, range 0 45.1\%, 35 samples) (Tab. 2).

The NMDS plot (based on 59 common taxa, after exclusion of 35 rare taxa) revealed a much stronger temporal than spatial influence on phytoplankton species composition in Mona Lake (Fig. 3). Sampling sites had more similar species compositions than sampling dates, i.e., samples from all 4 sites collected on the same date were clustered together as opposed to individual sites being clustered together across dates. However, there was a continuous change in species composition between months in both years (e.g., samples from adjacent months were closer to each other than to more distant months). Spring samples shared similar species (May, 2002 and May, 2003) as indicated by their close proximity to each other on the ordination plot. The two most separated clusters of samples (July and August 2003, right side of Fig. 3), collected 2 weeks to a month after algaecide treatment, had distinct species compositions; July samples were dominated by Stephanodiscus sp. Ehrenberg (relative biovol-

Tab. 1. Environmental variables summarized with their means $( \pm \mathrm{SD})$, and ranges for the Mona Lake dataset.

\begin{tabular}{|c|c|c|c|c|c|c|}
\hline \multirow[t]{2}{*}{ Environmental variables } & \multicolumn{2}{|c|}{ All samples $(\mathrm{n}=96)$} & \multicolumn{2}{|c|}{ Surface samples $(\mathrm{n}=\mathbf{4 8})$} & \multicolumn{2}{|c|}{ Bottom samples ( $\mathrm{n}=48)$} \\
\hline & Mean \pm SD & Range & Mean \pm SD & Range & Mean \pm SD & Range \\
\hline \multicolumn{7}{|l|}{ Algal biomass } \\
\hline Chlorophyll a $(\mu \mathrm{g} / \mathrm{L})$ & $18.22 \pm 14.85$ & $2.5-52.00$ & $18.10 \pm 11.85$ & $2.20-45.50$ & $18.34 \pm 20.20$ & $0-74.10$ \\
\hline \multicolumn{7}{|l|}{ Water quality } \\
\hline $\operatorname{Ammonia}(\mathrm{mg} / \mathrm{L})^{*}$ & $0.29 \pm 0.30$ & $0-1.52$ & $0.13 \pm 0.13$ & $0-0.49$ & $0.45 \pm 0.59$ & $0-3.01$ \\
\hline Chloride (mg/L) & $52.34 \pm 21.58$ & $26.00-107.00$ & $51.65 \pm 19.61$ & $29.00-100.00$ & $53.04 \pm 24.77$ & $21.00-122.00$ \\
\hline Conductivity $(\mu \mathrm{S} / \mathrm{cm})^{*}$ & $446.16 \pm 38.08$ & $372.80-553.50$ & $432.34 \pm 34.55$ & $387.10-509.60$ & $459.99 \pm 50.73$ & $358.50-644.00$ \\
\hline Dissolved oxygen $(\mathrm{mg} / \mathrm{L})^{*}$ & $7.14 \pm 3.05$ & $2.80-14.51$ & $9.94 \pm 2.23$ & $5.59-15.26$ & $4.33 \pm 4.33$ & $0-13.75$ \\
\hline Nitrate $(\mathrm{mg} / \mathrm{L})$ & $0.16 \pm 0.25$ & $0-0.82$ & $0.16 \pm 0.27$ & $0-0.93$ & $0.16 \pm 0.23$ & $0-0.78$ \\
\hline $\mathrm{pH}^{*}$ & $8.38 \pm 0.34$ & $7.76-9.06$ & $8.71 \pm 0.37$ & $7.83-9.23$ & $8.06 \pm 0.50$ & $7.36-9.04$ \\
\hline Soluble reactive phosphorus $(\mathrm{mg} / \mathrm{L})^{*}$ & $0.03 \pm 0.04$ & $0-0.15$ & $0.01 \pm 0.01$ & $0-0.04$ & $0.06 \pm 0.08$ & $0-0.30$ \\
\hline Sulphate $(\mathrm{mg} / \mathrm{L})$ & $35.84 \pm 7.27$ & $21.50-50.00$ & $36.65 \pm 6.22$ & $26.00-47.00$ & $35.04 \pm 9.39$ & $17.00-67.00$ \\
\hline Total alkalinity $(\mathrm{mg} / \mathrm{L})^{*}$ & $123.52 \pm 10.63$ & $89.50-143.00$ & $119.38 \pm 12.51$ & $88.00-144.00$ & $127.67 \pm 12.25$ & $91.00-155.00$ \\
\hline Total dissolved solids $(\mathrm{g} / \mathrm{L})^{*}$ & $0.29 \pm 0.02$ & $0.24-0.35$ & $0.28 \pm 0.02$ & $0.25-0.33$ & $0.29 \pm 0.03$ & $0.23-0.41$ \\
\hline Total Kjeldahl nitrogen $(\mathrm{mg} / \mathrm{L})^{*}$ & $1.00 \pm 0.44$ & $0.32-2.27$ & $0.80 \pm 0.40$ & $0.13-1.91$ & $1.20 \pm 0.84$ & $0.20-4.18$ \\
\hline Total phosphorus $(\mathrm{mg} / \mathrm{L})^{*}$ & $0.10 \pm 0.06$ & $0.03-0.25$ & $0.07 \pm 0.02$ & $0.03-0.13$ & $0.13 \pm 0.11$ & $0.03-0.42$ \\
\hline Turbidity (NTU) & $17.65 \pm 10.39$ & $3.80-55.10$ & $16.60 \pm 8.11$ & $4.90-39.60$ & $18.70 \pm 16.57$ & $0-94.20$ \\
\hline \multicolumn{7}{|l|}{ Physical characteristics } \\
\hline Temperature $\left({ }^{\circ} \mathrm{C}\right)^{*}$ & $16.78 \pm 6.96$ & $0.73-25.77$ & $17.97 \pm 7.84$ & $0-26.94$ & $15.60 \pm 6.24$ & $1.44-24.60$ \\
\hline Lake depth (m) & $6.15 \pm 1.52$ & $3.50-8.30$ & - & - & - & - \\
\hline Secchi depth $(m)^{\#}$ & $0.68 \pm 0.23$ & $0.25-1.20$ & - & - & - & - \\
\hline Light extinction coefficient & $2.09 \pm 0.52$ & $1.20-3.51$ & - & - & - & - \\
\hline
\end{tabular}

NTU, Nephelometric Turbidity Units; " Summaries based on $n=43$ (all, surface and bottom samples). "Significant difference (P<0.05) between surface and bottom samples.

Tab. 2. Most abundant phytoplankton species in Mona Lake $(n=48)$ summarized with their occurrence, mean relative biovolumes, and ranges (Min-Max).

\begin{tabular}{|c|c|c|c|c|c|c|}
\hline Species name & Division & FG & MBFG & $\mathrm{n}$ & Mean \pm SD $(\%)$ & Range (\%) \\
\hline Planktothrix agardhii (Gomont) Anagnostidis \& Komárek & Cyanobacteria & $\mathrm{S} 1$ & III & 31 & 15.224 .9 & $0-78.5$ \\
\hline Scenedesmus quadricauda (Turpin) Brébisson & Chlorophyta & $\mathrm{J}$ & IV & 37 & $9.9 \pm 13.7$ & $0-67.6$ \\
\hline Aphanizomenon gracile (Lemmermann) Lemmermann & Cyanobacteria & $\mathrm{H} 1$ & III & 18 & $8.4 \pm 17.5$ & $0-64.0$ \\
\hline Pseudanabaena sp. Lauterborn & Cyanobacteria & $\mathrm{S} 1$ & III & 35 & $8.0 \pm 11.2$ & $0-45.1$ \\
\hline Stephanodiscus sp. Ehrenberg & Bacillariophyta & $\mathrm{C}$ & VI & 7 & $5.9 \pm 18.6$ & $0-78.3$ \\
\hline Aphanizomenon flos-aquae & Cyanobacteria & H1 & III & 25 & $5.1 \pm 9.8$ & $0-41.6$ \\
\hline Microcystis aeruginosa (Kützing) Kützing & Cyanobacteria & $\mathrm{Lm}$ & VII & 10 & $5.0 \pm 12.1$ & $0-63.0$ \\
\hline Chlamydomonas globosa Snow & Chlorophyta & $\mathrm{X} 2$ & V & 17 & $4.0 \pm 14.0$ & $0-74.8$ \\
\hline Gymnodinium excavatum Van Meel & Dinophyta & Y & $\mathrm{V}$ & 22 & $3.3 \pm 7.0$ & $0-29.9$ \\
\hline Aphanizomenon issatschenkoi (Usacev) Proshkina-Lavrenko & Cyanobacteria & H1 & III & 17 & $3.3 \pm 12.1$ & $0-54.7$ \\
\hline
\end{tabular}

FG, functional group; $M B F G$, morphologically based functional group; $n$, number of samples. 
ume ranging between $47.6-78.3 \%$ at all four sites), $M i$ crocystis aeruginosa (Kützing) Kützing (12.8-32.7\% at all four sites), and $M$. viridis (Braun) Lemmermann (6.4$18.1 \%$ at sites 2 and 4 ), while most of the remaining species accounted for an average of $<1 \%$ of each sample's relative biovolume. August samples had four different $\mathrm{Mi}$ crocystis species (M. aeruginosa, 7.7-63.0\% at all sites; $M$. botrys Teiling, $31.7 \%$ at site $3 ; M$. viridis, $3.8-5.3 \%$ at sites 3 and 4; $M$. wesenbergii (Komárek) Komárek ex Komárek, 3.8-38.4\% at all sites), Aphanizomenon flosaquae Ralfs ex Bornet \& Flahault (16.5-41.6\% at all sites), and Anabaena spiroides Klebahn (25.7\% at site 1$)$.

Environmental variables that correlated highly with the ordination space defined by species composition included total phosphorus, temperature, and dissolved oxygen (Tab. 3). The first NMDS axis (NMDS I) defined a gradient from samples with high temperature, total phosphorus, and turbidity (e.g., summer samples, right side of
Fig. 3) to samples with high conductivity, dissolved oxygen, nitrate, and chloride (e.g., winter and spring samples) as indicated by the opposite direction of their corresponding vectors (Fig. 3). The second NMDS axis (NMDS II) was significantly $(\alpha \leq 0.05)$ positively correlated with ammonia and negatively correlated with $\mathrm{pH}$. Fall samples (September-October 2002) were arranged along this second axis. Very similar relationships were revealed by the phylogenetic and functional groups as well (data not shown). Spring samples were related to high dissolved oxygen and $\mathrm{pH}$, summer samples to high temperature and total phosphorus, fall samples to nitrate, while winter samples were highly correlated with high conductivity and chloride.

In terms of morphologically-based functional groups (MBFG), there were no striking differences among sites in either year. However, there were some distinct temporal patterns in relative biovolumes of groups III (large fila-

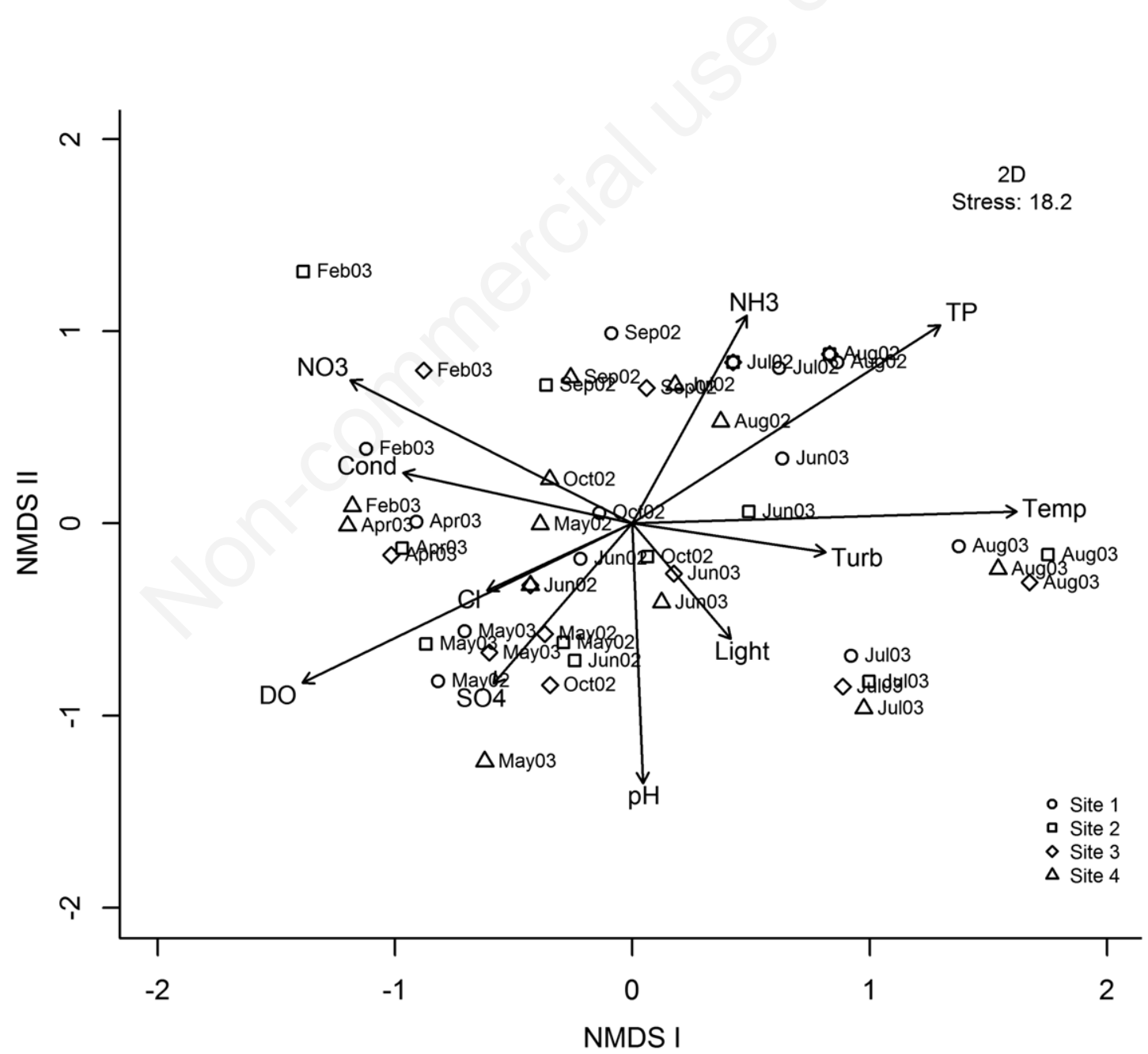

Fig. 3. Non-metric multidimensional scaling (NMDS) plot (two dimensions, stress 18.2) based on species composition of phytoplankton samples $(\mathrm{n}=48)$ from Mona Lake. Each sample is represented by its month and year of collection as well as its site location (site 1, Great Lake-influenced, through site 4, lotic-influenced), symbol legend in the lower right corner). See Fig. 1 for a map of site locations. Vectors indicate significant environmental variables $(\mathrm{P}<0.05)$ and their direction of largest change. Variable abbreviations are in Tab. 3. 
mentous cyanobacteria with aerotopes, Fig. 4A), V (unicellular flagellates of medium to large size, Fig. 4B), and VI (diatoms, Fig. 4C). Spring and summer were dominated by groups III and VI (Fig. 4 A,C), while group V was abundant in winter and early spring (Fig. 4B). In July and August of 2003 (after algaecide application), groups III and VI were more numerous than others.

Functional group (FG) classification also revealed no apparent site differences. However, there were temporal differences among the dominant functional groups. Summers were characterized mainly by group Lm (summer epilimnia in eutrophic lakes, Fig. 4E). Group H1 (nitrogen-fixing Nostocaleans, Fig. 4D) was present in most months, with higher abundances in late spring and early summer. Functional group S1 (turbid mixed waters, Fig. 4F) also was abundant in the summer when it averaged $83 \%$ and $87 \%$ in July and August of 2002, respectively. Despite its high relative abundance in the summer, group S1's overall relative biovolume decreased by $13 \%$ from site 1 (48.4\%, Great Lake-influenced) through site 4 (35.0\%, lotic-influenced). However, this trend was observed only for the relative biovolume data, not for the absolute values.

Phytoplankton communities were dominated on an annual basis by cyanobacteria followed by chlorophytes and diatoms (Fig. 5). Temporally, cyanobacteria comprised $>90 \%$ of the total biovolume in the summer. Relative contributions of cyanobacteria were the lowest in winter and spring, when they accounted for $<5 \%$ of the total biovolume in a sample. A decline in cyanobacterial abundance was observed in July 2003 when diatoms comprised the majority of the phytoplankton community (reaching their highest concentration) after algaecide treatment of the lake. However, cyanobacteria recovered by the following month
(August 2003) when their relative biovolumes were comparable to those from August 2002. The highest concentrations of chlorophytes were recorded in winter (February 2003) when sampling was conducted through the ice. Diatom relative abundances steadily increased from winter through late spring (May 2002 and 2003), and were almost absent in the following summers except after the algaecide application in July 2003. Fall was characterized by the presence of both chlorophytes and cyanobacteria.

The ordination based on species data was similar to the ordinations based on functional groups (MBFG and FG). In all of them, most samples were grouped based on time rather than space. However, the ordination based on FG resembled the one based on species data the most, including the sample clusters from July and August 2003 (after algaecide treatment). The ordination using MBFG resulted in less conspicuous sample groupings based on time. In all ordinations, one sample stood out as an outlier. This sample was collected on February 17, 2003 and was dominated by a chlorophyte Chlamydomonas globosa Snow (47.1\%), a dinoflagellate Glenodinium quadridens (Stein) Schiller (29.6\%), and a euglenoid Trachelomonas hispida (Perty) Stein (21.2\%).

\section{DISCUSSION}

Hydraulic residence time can have a major influence on lake biology and chemistry (Søballe and Kimmel, 1987; Schallenberg and Burns, 1997). Lakes with a short HRT flush quickly resulting in greater mixing of plankton and fewer opportunities for plankton to bloom or for nutrients to accumulate. In contrast, the opposite trends can occur in lakes with a long HRT. For example, Lindström and Bergström (2004) observed greater similarities in bacterioplankton assemblages in a short HRT lake compared

Tab. 3. Results from environmental vector fitting in the ordination space of the non-metric multidimensional scaling plot with variable scores along ordination axes (NMDS I-II), goodness-of-fit statistic $\left(\mathrm{r}^{2}\right)$ and its significance (P-values). Variables are listed in descending order of $\mathrm{r}^{2}$, while their summaries are in Tab. 1.

\begin{tabular}{|c|c|c|c|c|c|}
\hline Variable name (abbreviation) & NMIDS I & NMIDS II & $r^{2}$ & \multicolumn{2}{|c|}{ P-values } \\
\hline Total phosphorus (TP) & 0.85 & 0.53 & 0.73 & 0.001 & $* * *$ \\
\hline Temperature (Temp) & 1.00 & -0.05 & 0.67 & 0.001 & $* * *$ \\
\hline Dissolved oxygen (DO) & -0.91 & -0.42 & 0.63 & 0.001 & $* * *$ \\
\hline Nitrate $\left(\mathrm{NO}_{3}\right)$ & -0.81 & 0.58 & 0.48 & 0.001 & $* * *$ \\
\hline $\mathrm{pH}$ & -0.02 & -1.00 & 0.40 & 0.001 & $* * *$ \\
\hline Ammonia $\left(\mathrm{NH}_{3}\right)$ & 0.43 & 0.90 & 0.39 & 0.001 & $* * *$ \\
\hline Sulphate $\left(\mathrm{SO}_{4}\right)$ & -0.64 & -0.77 & 0.27 & 0.002 & $* *$ \\
\hline Conductivity (Cond) & -0.94 & 0.35 & 0.24 & 0.005 & $* *$ \\
\hline Turbidity (Turb) & 0.98 & -0.22 & 0.17 & 0.019 & $*$ \\
\hline Light Extinction Coefficient (Light) & 0.54 & -0.84 & 0.13 & 0.060 & \# \\
\hline Chloride $(\mathrm{Cl})$ & -0.89 & -0.45 & 0.13 & 0.058 & $\#$ \\
\hline Lake depth (Depth) & 0.76 & 0.65 & 0.04 & 0.419 & $\S$ \\
\hline
\end{tabular}

NMDS, non-metric multidimensional scaling; significance codes: ${ }^{* * *} 0 ;{ }^{* *} 0.001 ;{ }^{*} 0.01 ;{ }^{\#} 0.05 ;{ }^{8} 0.1$. P values based on 1000 permutations. 
a) MBFG III



b) MBFG V

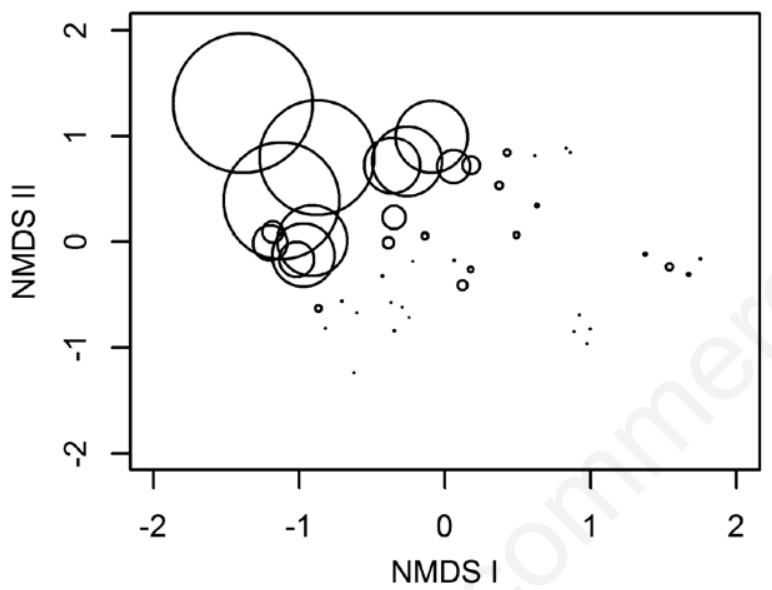

c) MBFG VI



d) FG H1



e) FG $\mathrm{Lm}$

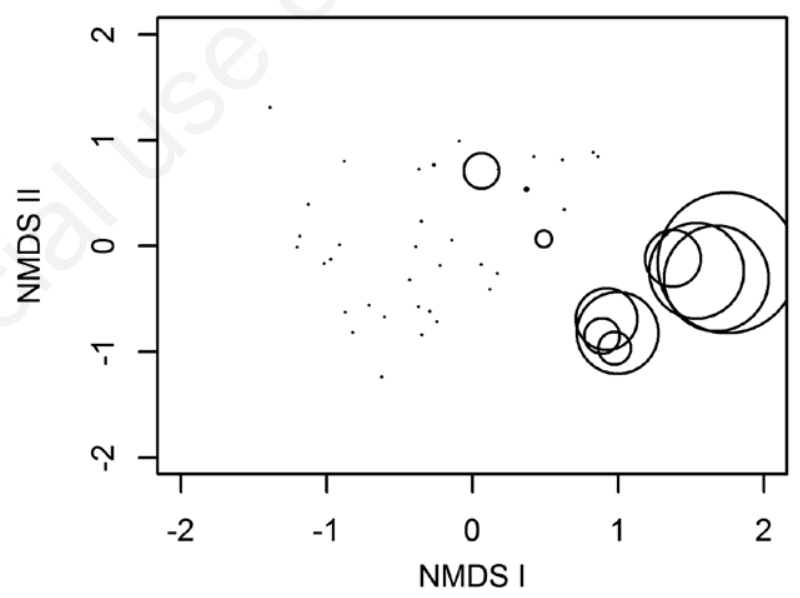

f) FG S1



Fig. 4. Non-metric multidimensional scaling (NMDS) plot (two dimensions, stress 18.2) based on species composition of phytoplankton samples $(n=48)$ from Mona Lake. Each sample is represented by one bubble whose diameter corresponds to the relative biovolume abundance of selected morphologically based functional groups (MBFG III, A; MBFG V, B; MBFG VI, C) and functional groups (FG H1, D; FG Lm, E; FG S1, F). The location of each season's label in the ordination space in Panel A applies to all other panels. See Fig. 3 for sample information. 
to a long HRT lake, although Beisner et al. (2006) noted that an organism's dispersal ability also can influence its growth patterns.

In the present study, despite the relatively short HRT of Mona Lake, we expected to detect some differences in phytoplankton spatial distribution given the system's three hydrologic zones (Great Lake-influenced, lotic-influenced, and transitional). However, no distinct spatial patterns were evident in terms of phytoplankton biovolume, species composition, and functional groups, despite this river-to-lake gradient. We hypothesize that the lack of spatial discrimination is a result of the lake's relatively small size and its horizontally well-mixed waters, although our relatively coarse sampling frequency (monthly) may have missed finer scale temporal changes. The perennial river inflows, short retention time, and potential water exchange with Lake Michigan (Evans, 1992) appears to result in a well-mixed phytoplankton community. A similar lack of spatial pattern in phytoplankton communities was observed in Muskegon Lake, another drowned-river mouth lake located $5 \mathrm{~km}$ north of Mona Lake (Gillett and Steinman, 2011).

Phytoplankton communities in Mona Lake revealed stronger patterns on a temporal than spatial scale. Similar to other shallow lakes (Romo et al., 2012), phytoplankton biovolume and species composition showed increased cyanobacterial dominance in the summer months. Cyanobacteria often dominate the phytoplankton community under warmer water temperatures (Kosten et al., 2012) and relatively calm conditions (Paerl and Huisman,
2008; Imai et al., 2009; Wynne et al., 2010). The temporal changes in phytoplankton species, i.e., the seasonal change from diatoms and chlorophytes (spring) through cyanobacteria (summer) to chlorophytes (fall and winter), conforms to previously described phytoplankton succession in north temperate lakes (Sommer et al., 1986; Reynolds, 1988). It is defined by physical factors such as temperature, turbulence, nutrient availability, and light (Reynolds, 1989). It is unclear if the inter-annual shift from Planktothrix agardhii-dominated assemblage in summer 2002 to Aphanizomenon flos-aquae-Microcystis in summer 2003 is due to natural conditions or the algaecide application. Such species shifts have been associated with low nitrogen to phosphorus ratios and reported from other eutrophic riverine lakes in Northern Europe (Teubner et al., 1999). However, since our summer samples in 2003 were collected 2 to 4 weeks after algaecide application and there were no noticeable changes in environmental conditions, we can only speculate about the causes of such shifts in species composition. MBFG seasonal succession mirrored the species-based one despite its independence from taxonomic affiliations. The MBFG is based on morphological features and size, and while some groups are taxonomically homogeneous (e.g., group VI includes all diatoms), others include species across divisions (Kruk et al., 2010). The dominance of group III species through spring and summer (especially in 2002) is likely attributable to both their large size, which makes them resistant to grazing, and the presence of gas vesicles, which enables them to persist longer in the water column

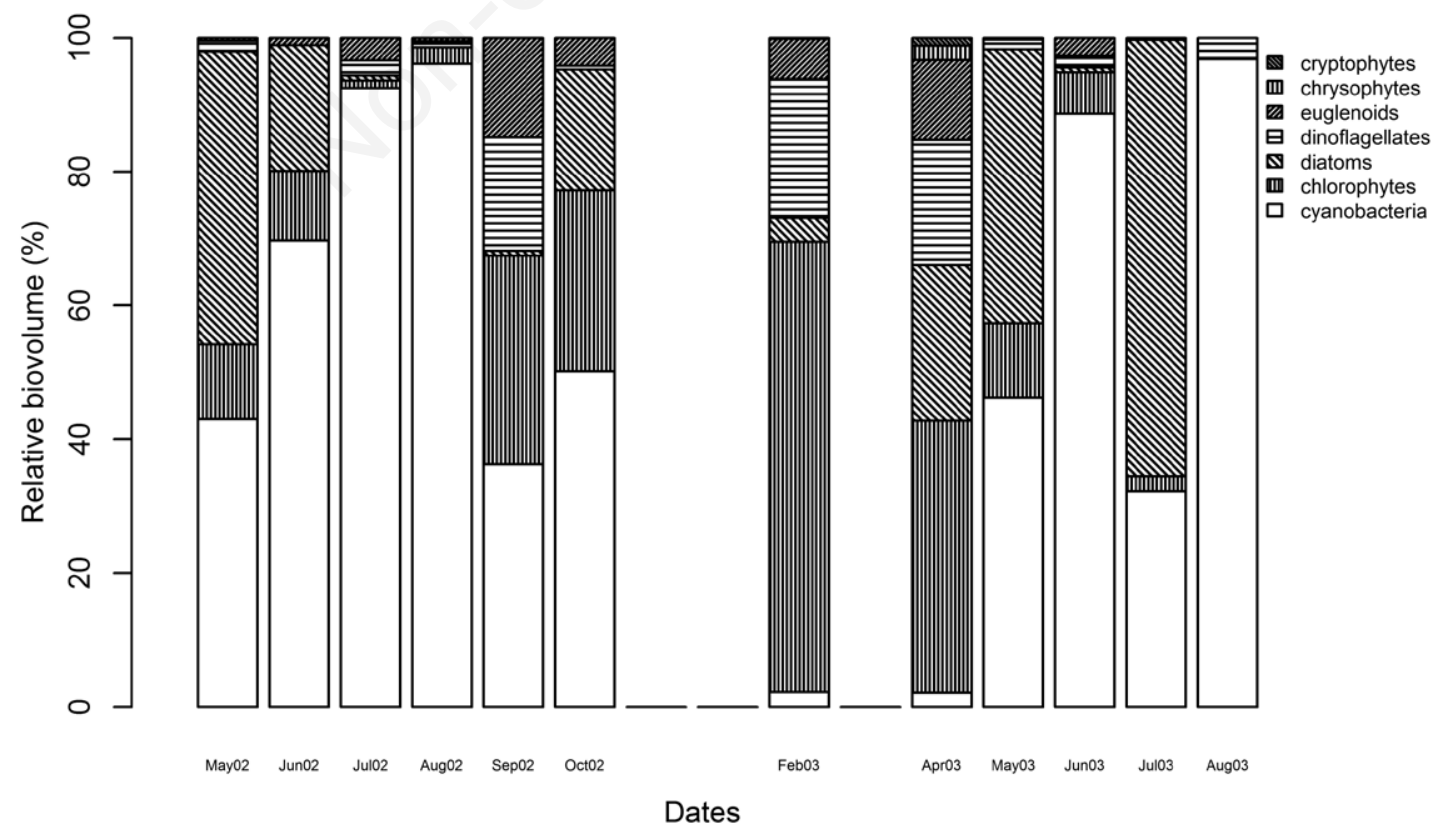

Fig. 5. Stacked barplots for relative biovolume of algal divisions for each sampling period at all four lake sites. 
and gain access to light and nutrients (Kruk et al., 2010). The abundance of group V in winter and early-spring samples might be explained by their moderate size and mobility (possession of flagella), which allows them favorable positioning for resource acquisition (Kruk et al., 2010) during periods of limited light availability and higher turbulence. Functional groups Lm, H1, and S1 are usually dominant during the growing season (Borics et al., 2012). Group Lm (abundant in the summer of 2003) includes Microcystis aeruginosa, whose large colony size and motility enable it to harvest resources at different depths under stratified conditions (Reynolds et al., 2002). Group H1 includes eutrophic N-fixing species, which were abundant in late spring and early summer when either nitrogen or both phosphorus and nitrogen are the limiting nutrients in the lake (Biddanda et al., 2008). Group S1 (solitary filamentous cyanobacteria), which was most abundant in the summer of 2002, is specific to enriched and shallow lakes such as Mona Lake.

There was a lack of a distinct response in biovolume after the sewage spill in summer 2002, but there was a noticeable response in phytoplankton species composition. The spill happened near site 3 and seemed to impact phytoplankton at that site and the ones downlake of it (sites 1 and 2), compared to site 4 (above the spill). Also, after the spill the species richness was the second lowest ( 8 taxa) recorded in our study. The phytoplankton community at that time was dominated by eutrophic, and potentially cyanotoxin-forming species, such as Aphanizomenon flosaquae $(>16 \%)$, Microcystis aeruginosa $(<8 \%)$, and $M$. wesenbergii $(<4 \%)$. The Mona Lake phytoplankton exhibited a larger change in species composition after the lake-wide algaecide application in summer 2003. Following the algaecide treatment, cyanobacteria were still present and diverse but a diatom species (Stephanodiscus $s p$.) became most abundant, reaching its highest relative abundance ( $>48 \%) 12$ days after the treatment. This diatom belongs to a genus with no common ecological preference (Stoermer and Julius, 2003). Species in this genus occur in different trophic conditions, including highly eutrophic waters with severe silica depletion (Stoermer and Julius, 2003). However, because silica was not measured in this study and none of the nutrient concentrations in July were higher than usual, it is unclear if nutrients acted as a stimulus for the growth of Stephanodiscus sp. The next most abundant taxa after algaecide application were Microcystis aeruginosa $(<33 \%)$ and $M$. viridis $(<18 \%)$, possibly indicating a recovered algal community as these two taxa are commonly found within 7-21 days after treatment (Hanson and Stefan, 1984). Algaecide (copper sulphate) treatment results in reduced algal biomass but its efficacy depends on the activity of ionic copper, lake water chemistry (e.g., $\mathrm{pH}$, hardness, alkalinity, conductivity), and algal sensitivity (e.g., algal species have variable tolerance to copper toxicity) (McKnight et al., 1983). Algaecide applications in Mona Lake during the summers of 19701975 resulted in control of phytoplankton levels and delayed phytoplankton blooms (Freedman et al., 1979).

The most important environmental variables structuring phytoplankton communities in Mona Lake varied seasonally and they included dissolved oxygen and $\mathrm{pH}$ in spring, total phosphorus and temperature in summer, and ammonia in fall. High dissolved oxygen concentrations in the spring correlated with low phytoplankton biovolume, which presumably resulted from low temperatures. Herbivory at this time of the year is thought to be negligible given typically low zooplankton biomass (Makarewicz et al., 1995), although we did not measure this in Mona Lake. Similar to other studies (Freedman et al., 1979; Huszar and Caraco, 1998), high total phosphorus concentrations and high temperatures correlated with the highest phytoplankton biovolumes, which were measured in the summer of 2003. During summer stratification and anoxic conditions, internal phosphorus loading accounts for $68-82 \%$ of the overall phosphorus load in Mona Lake (Steinman et al., 2009), and may be responsible for promoting and maintaining algal blooms (Cymbola et al., 2008). These blooms may be prolonged into the fall season when lake turnover brings up bottom waters high in phosphorus and ammonia (Freedman et al., 1979; Steinman et al., 2006), which is the preferred source of nitrogen for algae. Recent studies have indicated that the phytoplankton in Mona Lake appear to be limited by either nitrogen or co-limited by phosphorus and nitrogen (Steinman et al., 2006; Biddanda et al., 2008).

Despite the flow-through hydrologic characteristics of this lake system, the observed phytoplankton seasonal changes agreed relatively well with the ones predicted by conventional phytoplankton models such as PEG (Sommer et al., 1986). Similar to the model, our spring samples were abundant in chlorophytes and diatoms but the chlorophytes were replaced by cyanobacteria in late spring, not in the summer. This earlier seasonal shift toward cyanobacteria may be attributed to earlier warming associated with climate change (Pearl and Huisman, 2008 ) and to the lake's phosphorus-rich conditions (Steinman et al., 2006; Biddanda et al., 2008; Steinman et al., 2009), which favour cyanobacteria (Schindler, 1977; Downing et al., 2001), and especially nitrogen fixing cyanobacteria (e.g., Anabaena, Aphanizomenon), over other algae (Sommer et al., 1986; Tilman et al., 1986). Nitrogen fixers were not common in the lake in the early 1970's (Freedman et al., 1979), perhaps because of the elevated nitrogen concentrations at that time. Summer dominance by cyanobacteria may be a characteristic of eutrophic lakes regardless of lake stratification (Sommer et al., 1986). In addition, the gradual decline in total nitrogen to total phosphorus ratio from spring to autumn 
might be a potential driver for the seasonal increase in cyanobacterial biomass in the lake (Biddanda et al., 2008). The cyanobacterial dominance continued throughout the summer in both our study years, with a minor interruption in July 2003 when an algaecide treatment of the lake resulted in a change in species composition towards diatoms. Unlike the PEG model, fall was still dominated by cyanobacteria (albeit less so than in the summer) and chlorophytes. Such gradual changes in biomass from summer to autumn may be more characteristic of eutrophic lakes (Sommer et al., 1986) where climate change might prolong summer stratification and the cyanobacterial growth season (Pearl and Huisman, 2008). During winter stratification when the lake is frozen and nutrients concentrations are low (Steinman et al., 2006), the phytoplankton community was dominated by chlorophytes and dinoflagellates. These algal groups are not uncommon for ice-covered eutrophic lakes (Wiedner and Nixdorf, 1998) but this finding disagrees with the PEG model's prediction of winter dominance by diatoms. De Senerpont Domis et al. (2012) noted that system-based deviations from PEG are to be expected because it emphasizes physical factors, grazing, and nutrients rather than biological drivers such as microbial organisms, parasites, and fish.

\section{CONCLUSIONS}

River-mouth ecosystems provide diverse and critical habitats in the Great Lakes (Jude and Pappas, 1992; Bhagat and Ruetz, 2011; Larson et al., 2013). The current study examined phytoplankton communities from both traditional (taxonomic) and less traditional (i.e., functional groups) perspectives in an attempt to better understand their spatial and temporal variability in a drowned rivermouth lake. There was a good agreement between the seasonal successions of species and MBFG classification, while both species and functional classifications (FG and MBFG) reflected similar environmental conditions. Phytoplankton dynamics in Mona Lake were partially explained by the PEG model; our observations revealed different fall (cyanobacteria and chlorophytes) and winter (chlorophytes and dinoflagellates) communities than predicted by PEG. Our data indicate that there is a strong seasonal change in phytoplankton with summer biovolume dominated by cyanobacteria, which are stimulated by the high phosphorus concentrations in the lake. This seasonal change conformed relatively well to the PEG model, which might have predictive applications in the management of the lake (e.g., control of algal blooms). A sewage spill reduced taxa richness to a minimum while an algaecide application resulted in changes in species composition. These two events, while unexpected, may be symptomatic of future conditions, as human pressures are anticipated to grow in river-mouth systems such as Mona Lake. In addition, expected increases in air temperature associated with climate change may lead to lower water levels and longer periods of sustained low flow, perhaps resulting in greater opportunity for hydrologic zonation and distinct phytoplankton differences within drowned river mouth systems. It is unclear if episodic storm events, and associated stormwater runoff (Hayhoe et al., 2010), will disrupt these distinct anticipated phytoplankton assemblages. Regardless, these climate- and human-induced changes can profoundly impact phytoplankton through longer growing seasons, deeper thermoclines, increased internal nutrient loading, shifts in community composition toward toxic cyanobacteria (Jöhnk et al., 2008; Markensten et al., 2010), and altered ecosystem functions (Carey et al., 2012; Paerl and Paul, 2012; North et al., 2014).

\section{ACKNOWLEDGEMENTS}

We are grateful to all AWRI staff who assisted in the collection and analysis of water quality samples from Mona Lake. We express additional gratitude to Kurt Thompson (Grand Valley State University) for making the map, and to Dr. Yangdong Pan and his students at Portland State University for reviewing the manuscript. Funding was provided by a Johnson-Hines postdoctoral fellowship and the Community Foundation for Muskegon County.

\section{REFERENCES}

Albert DA, Wilcox DA, Ingram JW, Thompson TA, 2005. Hydrogeomorphic classification for Great Lakes coastal wetlands. J. Great Lakes Res. 31(Suppl.1):126-146.

APHA, 1999. Standard methods for the examination of water and waste water, 20th ed. American Public Health Association. Washington, DC USA.

Beisner BE, Peres-Neto PR, Lindström ES, Barnett A, Longhi ML, 2006. The role of environmental and spatial processes in structuring lake communities from bacteria to fish. Ecology 87:2985-2991.

Bhagat Y, Ruetz CR III, 2011. Temporal and fine-scale variation in fish assemblage structure in a drowned river mouth system of Lake Michigan. Trans. Am. Fish Soc. 140:1429-1440.

Biddanda B, Steinman AD, Nemeth L, Rediske R, Hong Y, Kendall S, 2008. Nutrient bioassays of plankton biomass and metabolism in an urbanized drowned river-mouth lake, Mona Lake, Michigan. J. Freshwater Ecol. 23:41-53.

Borics G, Varbiro G, Grigorszky I, Krasznai E, Szabo S, Kiss KT, 2007. A new evaluation technique of potamoplankton for the assessment of the ecological status of rivers. Arch. Hydrobiol. 161:465-486.

Borics G, Tothmeresz B, Lukacs BA, Varbiret G, 2012. Functional groups of phytoplankton shaping diversity of shallow lake ecosystems. Hydrobiologia 698:251-262.

Bray JR, Curtis JT, 1957. An ordination of the upland forest communities of southern Wisconsin. Ecol. Monogr. 27:325-349.

Carey CC, Ibelings BW, Hoffmann EP, Hamilton DP, Brookes JD, 2012. Eco-physiological adaptations that favour freshwater cyanobacteria in a changing climate. Water Res. 46:1394-1407. 
Clarke KR, 1993. Non-parametric multivariate analysis of changes in community structure. Aust. J. Ecol. 18:117-143.

Cymbola J, Ogdahl M, Steinman AD, 2008. Phytoplankton response to light and internal phosphorus loading from sediment release. Freshwater Biol. 53:2530-2542.

De Senerpont Domis L, Elser J, Gsell A, Huszar V, Ibelings B, Jeppesen E, Kosten S, Mooij W, Roland F, Sommer U, Van Donk E, Winder M, Lürling M, 2012. Plankton dynamics under different climatic conditions in space and time. Freshwater Biol. 58:463-482.

Downing JA, Watson SB, McCauley E, 2001. Predicting cyanobacteria dominance in lakes. Can. J. Fish. Aquat. Sci. 58:1905-1908

Evans ED, 1992. Mona, White, and Muskegon Lakes in Muskegon County, Michigan. The 1950s to the 1980s. Michigan Department of Natural Resources, Lansing, MI.

Freedman P, Canale R, Auer M, 1979. The impact of wastewater diversion spray irrigation on water quality in Muskegon County lakes. US EPA 905/9-79-006-A, US Environmental Protection Agency, Washington, DC, USA.

Gillett ND, Steinman AD, 2011. An analysis of long-term phytoplankton dynamics in Muskegon Lake, a Great Lakes Area of Concern. J. Great Lakes Res. 37:335-342.

Hanson MJ, Stefan HG, 1984. Side effects of 58 years of copper sulfate treatment of the Fairmont Lakes, Minnesota. J. Am. Water Resour. As. 20:889-900.

Hayhoe K, VanDorn J, Croley II T, Schegal N, Wuebbles D, 2010. Regional climate change projections for Chicago and the US Great Lakes. J. Great Lakes Res. 36:7-21.

Hillebrand H, Dürselen C-D, Kirschtel D, Pollingher U, Zohary $\mathrm{T}, 1999$. Biovolume calculation for pelagic and benthic microalgae. J. Phycol. 35:403-424.

Hong Y, Steinman AD, Biddanda B, Rediske R, Fahnenstiel G, 2006. Occurrence of toxin-producing cyanobacterium Cylindrospermopsis raciborskii in Mona and Muskegon Lakes, Michigan. J. Great Lakes Res. 32:645-652.

Hutchinson GE, 1961. The paradox of the plankton. Am. Nat. 95:137-145.

Huszar V, Caraco N, 1998. The relationship between phytoplankton composition and physical-chemical variables: a comparison of taxonomic and morphological-functional descriptors in six temperate lakes. Freshwater Biol. 40:679-696.

Ibelings BW, Chorus I, 2007. Accumulation of cyanobacterial toxins in freshwater "seafood" and its consequences for public health: a review. Environ. Pollut. 150:177-192.

Imai H, Chang K-H, Kusaba M, Nakano S-I, 2009. Temperature-dependent dominance of Microcystis (Cyanophyceae) species: M. aeruginosa and $M$. wesenbergii. J. Plankton. Res. 31:171-178.

Jöhnk KD, Huisman J, Sharples J, Sommeijerz B, Visser PM, Stroom JM, 2008. Summer heat waves promote blooms of harmful Cyanobacteria. Glob. Change Biol. 14:495-512.

Jude DJ, Pappas J, 1992. Fish utilization of Great Lakes coastal wetlands. J. Great Lakes Res. 18:651-672.

Kosten S, Huszar VLM, Bécares E, Costa LS, van Donk E, Hansson L-A, Jeppesen E, Kruk C, Lacerot G, Mazzeo N, De Meester L, Moss B, Lürling M, Nõges T, Romo S, Scheffer M, 2012. Warmer climates boost cyanobacterial dominance in shallow lakes. Glob. Change Biol. 18:118-126.

Kruk C, Huszar VLM, Peeters ETHM, Bonilla S, Costa L, Lür- ling M, Reynolds CS, Scheffer M, 2010. A morphological classification capturing functional variation in phytoplankton. Freshwater Biol. 55:614-627.

Larson JH, Trebitz A, Steinman AD, Wiley MJ, Carlson-Mazur M, Pebbles V, Braun H, Seelbach P, 2013. Great Lakes rivermouth ecosystems: scientific synthesis and management implications. J. Great Lakes Res. 39:513-524.

Lindström ES, Bergström AK, 2004. Influence of inlet bacteria on bacterioplankton assemblage composition in lakes of different hydraulic retention time. Limnol. Oceanogr. 49:125-136.

Litchman E, Klausmeier CA, 2008. Trait-based community ecology of phytoplankton. Annu. Rev. Ecol. Evol. S. 39:615-639.

Litchman E, Pinto P, Klausmeier C, Thomas M, Yoshiyama K, 2010. Linking traits to species diversity and community structure in phytoplankton. Hydrobiologia 653:15-28.

Makarewicz JC, Bertram P, Lewis T, Brown Jr EH, 1995. A decade of predatory control of zooplankton species composition of Lake Michigan. J. Great Lakes Res. 21:620-640.

Markensten H, Moore K, Persson I, 2010. Simulated lake phytoplankton composition shifts toward cyanobacteria dominance in a future warmer climate. Ecol. Appl. 20:752-767.

McKnight DM, Chisholm SW, Harleman DRF, 1983. CuSO treatment of nuisance algal blooms in drinking water reservoirs. Environ. Manage. 7:311-320.

Narwani A, Alexandrou MA, Oakley TH, Carroll IT, Cardinale BJ, 2013. Experimental evidence that evolutionary relatedness does not affect the ecological mechanisms of coexistence in freshwater green algae. Ecol. Lett. 16:1373-1381.

North RP, North RL, Livingstone DM, Köster O, Kipfer R, 2014. Long-term changes in hypoxia and soluble reactive phosphorus in the hypolimnion of a large temperate lake: consequences of a climate regime shift. Glob. Change Biol. 20:811-823.

Oksanen J, Blanchet FG, Kindt R, Legendre P, O'Hara RB, Simpson GL, Solymos P, Henry M, Stevens H, Wagner H, 2009. Vegan: community ecology package. R package, ver. 1.15-3. Available from: L http://vegan.r-forge.r-project.org

Padisak J, Crossetti LO, Naselli-Flores L, 2009. Use and misuse in the application of the phytoplankton functional classification: a critical review with updates. Hydrobiologia 621:1-19.

Paerl HW, Huisman J, 2008. Blooms like it hot. Science 320: 57-58.

Paerl HW, Paul VJ, 2012. Climate change: links to global expansion of harmful cyanobacteria. Water Res 46:1349-1363.

R Development Core Team, 2012. R: a language and environment for statistical computing. R Foundation for Statistical Computing, Vienna, Austria. Available from: http://www.Rproject.org

Reynolds CS, 1988. Functional morphology and the adaptive strategies of freshwater phytoplankton, p. 338-433. In: C.D. Sandgren (ed.), Growth and reproductive strategies of freshwater phytoplankton. Cambridge University Press, Cambridge.

Reynolds CS, 1989. Physical determinants of phytoplankton succession, p. 9-56. In: U. Sommer (ed.), Plankton ecology. Succession in Plankton Communities. Springer, Berlin, Heidelberg.

Reynolds C, Huszar V, Kruk C, Naselli-Flores L, Melo S, 2002. Towards a functional classification of the freshwater phytoplankton. J. Great Lakes Res. 24:417-428. 
Riseng CM, Wiley MJ, Seelbach PW, Stevenson RJ, 2010. An ecological assessment of Great Lakes tributaries in the Michigan Peninsulas. J. Great Lakes Res. 36:505-519.

Romo S, Soria J, Fernández F, Ouahid Y, Barón-Solá Á, 2012. Water residence time and the dynamics of toxic cyanobacteria. Freshwater Biol. 58:513-522.

Schallenberg M, Burns CW, 1997. Phytoplankton biomass and productivity in two oligotrophic lakes of short hydraulic residence time. New Zeal. J. Mar. Fresh. 31:119-134.

Schindler DW, 1977. Evolution of phosphorus limitation in lakes. Science 46:260-262.

Søballe DM, Kimmel BL, 1987. A large-scale comparison of factors influencing phytoplankton abundance in rivers, lakes, and impoundments. Ecology 68:1943-1954.

Sommer U, Gliwicz ZM, Lampert W, Duncan A, 1986. The PEG-Model of seasonal succession of planktonic events in fresh waters. Arch. Hydrobiol. 106:433-471.

Steinman A, Chu X, Ogdahl M, 2009. Spatial and temporal variability of internal and external phosphorus loads in Mona Lake, Michigan. Aquat. Ecol. 43:1-18.

Steinman A, Rediske R, Denning R, Nemeth L, Chu X, Uzarski D, Biddanda B, Luttenton M, 2006. An environmental assessment of an impacted, urbanized watershed: the Mona Lake Watershed, Michigan. Arch. Hydrobiol. 166:117-144.

Stoermer EF, Julius ML, 2003. Centric diatoms, p. 559-594. In: J.D. Wehr and R.G. Sheath (eds.) Freshwater algae of North America. Academic Press, San Diego.

Teubner K, Feyerabend R, Henning M, Nicklisch A, Woitke P, Kohl J-G, 1999. Alternative blooming of Aphanizomenon flos-aquae or Planktothrix agardhii induced by the timing of the critical nitrogen: phosphorus ratio in hypertrophic riverine lakes. Arch. Hydrobiol. Spec. Issue Adv. Limnol. 54:325-44.

Tilman D, Kiesling R, Sterner R, Kilham S, Johnson F, 1986. Green, bluegreen and diatom algae: taxonomic differences in competitive ability for phosphorus, silicon and nitrogen. Arch. Hydrobiol. 106:473-485.

Trebitz AS, Brazner JC, Pearson MS, Peterson GS, Tanner DK, Taylor DL, West CW, Hollenhorst TP, 2009. Geographic, anthropogenic, and habitat influences on Great Lakes coastal wetland fish assemblages. Can. J. Fish Aquat. Sci. 66:13431354.

US EPA, 1983. Methods for chemical analysis of water and wastes. US Environmental Protection Agency, Cincinnati, $\mathrm{OH}$, USA.

Utermöhl H, 1958. [Zur Vervollkommnung der quantitativen Phytoplankton Methodik].[Article in German]. Verh. Internat. Verein. Limnol. 9:1-38.

Wiedner C, Nixdorf B, 1998. Success of chrysophytes, cryptophytes and dinoflagellates over blue-greens (cyanobacteria) during an extreme winter (1995/96) in eutrophic shallow lakes. Hydrobiologia 369/370:229-235.

WHO, 1999. Toxic cyanobacteria in water: a guide to their public health consequences, monitoring and management. E \& FN Spon, London, England.

Wynne TT, Stumpf RP, Tomlinson MC, Dyble J, 2010. Characterizing a cyanobacterial bloom in western Lake Erie using satellite imagery and meteorological data. Limnol. Oceanogr. 55:2025-2036. 